\title{
PEMBELAJARAN MATEMATIKA BERBASIS MASALAH
}

\author{
Kiki Herdiansyah ${ }^{1}$ \\ ${ }^{1}$ Institut Agama Islam Negeri Metro \\ email: holmeskiki07@gmail.com
}

\begin{abstract}
The purpose of mathematics learning is the student will have high order thinking. This will be needed by student to solve their problems. Learning approach like teachercentered study can not develop their high order thinking. High order thinking is a thinking-level involve bloom's taxonomics. One of the student-centered learning is problem based learning. It can develop a high order thinking in mathematics. This article will show up to you about the problem-based mathematics learning
\end{abstract}

Keyword: Problem Based Learning, mathematics

\section{PENDAHULUAN}

Matematika merupakan salah satu materi yang mendasari perkembangan bidang teknologi dan informasi. Hal itu didukung juga dari kegunaan matematika sampai sekarang ini yang dapat diaplikasikan sebagai cara untuk memecahkan masalah dan persoalan kehidupan yang memerlukan kemampuan menghitung, mengukur, menyampaikan informasi, dan juga pengambilan keputusan. Kenyataan itu menuntut setiap orang agar memiliki kemampuan menggunakan matematika untuk dapat berpikir kritis, logis, terpola, konsisten, dan sistematis. Namun demikian, banyak peserta didik yang masih merasa kesulitan dalam mempelajari dan menerapkan matematika dalam kehidupan sehari-hari sehingga fungsi dan kegunaan matematika menjadi kurang bermakna.
Para peserta didik lebih memandang mata pelajaran matematika sebagai mata pelajaran yang berisi rumus-rumus yang harus dihafalkan tanpa dapat merasakan makna matematika itu sendiri. Berbagai usaha dan perubahan telah dilakukan oleh guru misalnya dengan mengujicobakan berbagai metode pembelajaran namun hal itu belum menunjukkan hasil yang optimal. Masih banyak peserta didik yang merasa kesulitan memahami matematika, tidak hanya dari materinya, tetapi juga cara penyampaian guru yang terkadang masih sulit diterima peserta didik.

Masalah lain yang muncul adalah pembelajaran matematika di kelas masih berfokus kepada guru sebagai satu-satunya sumber pengetahuan. Pemerintah melalui Kemendikbud telah mengembangkan dan mengimplementasikan kurikulum baru se- 
bagai salah satu terobosan pada bidang Pendidikan, yaitu kurikulum 2013. Salah satu tugas guru adalah mengubah pandangan pembelajaran yang berpusat pada guru menjadi pembelajaran berpusat pada siswa yang memungkinkan siswa dapat terlibat aktif dalam pembelajaran dan saling bekerja sama dalam menemukan pengetahuannya. Proses pembelajaran yang dikehendaki dalam kurikulum 2013 dan kurikulum-kurikulum sebelumnya adalah pembelajaran yang mengedepankan pengalaman personal melalui observasi (menyimak, melihat, membaca, men-dengar), bertanya, menyimpulkan, dan mengomunikasikan.

Berpijak dari hal tersebut, perlu adanya perbaikan strategi yang diterapkan dalam pembelajaran. Salah satu solusinya, yaitu dengan menerapkan model problem based learning. Model Problem Based Learning adalah suatu model pembelajaran yang menggunakan masalah dunia nyata sebagai suatu konteks bagi siswa untuk belajar tentang cara berpikir tingkat tinggi dan keterampilan pemecahan masalah, serta untuk memperoleh pengetahuan dan konsep yang esensial dan materi pelajaran.

\section{PEMBAHASAN}

\section{Definisi Problem Based Learning}

Salah satu model pembelajaran yang dianggap mampu mengembangkan kemampuan berpikir tingkat tinggi peserta didik adalah model problem based learning. Gunantara dkk (2014) menyatakan bahwa model problem based learning merupakan model pembelajaran yang bersifat kontekstual yang mengembangkan kemandirian belajar peserta didik dan menyenangkan. Peserta didik dituntut untuk mampu memetik suatu makna dari pembelajaran yang berbasis masalah, baik itu dalam pelajaran matematika ataupun pelajaran lainnya. Model ini diharapkan mampu menumbuhkan motivasi peserta didik, karena dalam prosesnya peserta didik menjadi objek utama.

Pembelajaran berbasis masalah dalam matematika sangat menarik bila diterapkan dengan baik. Peserta didik akan berusaha untuk menghubungkan pengalaman yang ada pada dirinya dengan masalah yang diberikan. Arends (dalam Hariyati dkk, 2013) mengatakan bahwa Problem Based Learning merupakan suatu model pembelajaran peserta didik mengerjakan permasalahan yang otentik dengan maksud untuk menyusun pengetahuan mereka sendiri, mengembangkan inkuiri dan ketrampilan lebih tinggi. Dengan demikian Problem Based Learning merupakan suatu model instruksional antara guru dengan peserta didik melalui pemecahan masalah berdasarkan pengalaman peserta didik itu sendiri.

Pembelajaran matematika yang berbasis masalah diharapkan mampu menum- 
buhkan kemandirian belajar dan rasa percaya diri peserta didik. Kemandirian belajar tersebut diperoleh dari cara peserta didik belajar secara individu melalui suatu masalah. Peserta didik akan berusaha mengaitkan pengalaman yang telah dimilikinya untuk menjadi sebuah pijakan dalam mempelajari masalah. Rasa percaya diri akan tertanam secara tidak langsung karena adanya kemandirian belajar. Akan muncul suatu sinergi yang saling berhubungan dalam diri peserta didik.

Hariyati dkk (2013) menyatakan sebagai berikut:

Peserta didik yang belajar melalui Problem Based Learning diberi kesempatan untuk mengembangkan kemampuannya dalam berpikir. Selanjutnya, guru hanya berperan fasilitator, dalam hal ini memfasilitasi konstruksi dalam mengolaborasi pengetahuan peserta didik. Diharapkan nantinya dengan model ini peserta didik mampu menyelesaikan permasalahan yang dihadapi berdasarkan pengalamannya.

Berdasarkan pendapat di atas, proses membangun suatu kompetensi dalam belajar difasilitasi oleh guru. Guru harus memiliki skill yang baik dan mampu melihat potensi yang dimiliki oleh peserta didiknya. Guru tidak boleh "íkut campur" terlalu dalam pada saat peserta didik belajar. Mereka harus diberi kesempatan yang cukup dan terus dibimbing agar proses belajarnya tidak mengarah ke kesimpulan yang salah.

Herman (2007) menyatakan bahwa model Problem Based Learning merupakan suatu pendekatan pembelajaran yang diawali dengan menghadapkan siswa dengan masalah matematika. Dengan segenap pengetahuan dan kemampuan yang telah dimilikinya, siswa dituntut untuk menyelesaikan masalah yang kaya dengan konsep-konsep matematika.

Permana \& Sumarmo

(2007)

menyatakan bahwa memperhatikan karakteristiknya, pada dasarnya PBM adalah menganut pandangan konstruktivisme. Dalam pandangan tersebut, peserta didik belajar secara. aktif dalam membangun pengetahuannya melalui proses asimilasi dan akomodasi dan interaksi dengan lingkungannya. Untuk mendukung berlangsungnya interaksi peserta didik. dengan lingkungannya dan atau dengan dirinya sendiri maka pengetahuan baru yang disajikan hendaknya berkaitan dengan pengetahuan awal peserta didik. Dengan demikian, terbangun pemahaman yang bermakna pada diri peserta didik. Pengetahuan awal yang dimiliki peserta didik sebaiknya diidentifikasi oleh guru sejak dimulainya proses pembelajaran di kelas.

Cara mengetahui pengetahuan awal peserta didik, yaitu dengan melakukan kegiatan pretest. Pretest dilaksanakan bukan ketika akan melakukan penelitian saja atau sekadar membandingkan dengan prestasi belajar ketika pembelajaran telah selesai dilakukan. Selain itu, cara lain yang bisa ditempuh guru adalah dengan melihat 
catatan prestasi belajar peserta didik sebelumnya.

Ratnaningsih (2003) menyatakan bahwa pembelajaran berbasis masalah adalah suatu pembelajaran yang menuntut aktivitas mental peserta didik untuk memahami suatu konsep pembelajaran melalui situasi dan masalah yang disajikan pada awal pembelajaran. Mental peserta didik ditempa dan dibiasakan untuk berhadapan dengan masalah sehingga akan terbentuk pribadi peserta didik yang memiliki bertanggungjawab dan menggunakan bukti autentik dalam pemecahan masalah.

Fitri (2011) menyebutkan bahwa sebuah permasalahan dapat memberikan kesempatan pada peserta didik untuk berani mencoba, mengaplikasikan pengetahuan, mengadopsi pemahaman baru, dan memberikan pengalaman sebagai seorang penemu. Hal ini berkaitan dengan model Problem Based Learning yang dianggap mampu meningkatkan kompetensi peserta didik.

Berdasarkan pendapat-pendapat di atas dapat disimpulkan bahwa model Problem Based Learning atau pembelajaran berbasis masalah, yaitu suatu model pembelajaran yang berpijak dari adanya suatu masalah, dimana guru sebagai fasilitator membimbing peserta didik. Model Problem Based Learning mampu mengembangkan rasa bertanggung jawab dan percaya diri, kemandirian belajar, dan kemampuan mengkonstruksi pengetahuan peserta didik.

\section{Tahapan dan Penilaian Model Problem Based Learning}

Tahapan pelaksanaan pembelajaran model Problem Based Learning terdapat dalam tabel berikut

Tabel 1.

Tahap Pelaksanaan Model Problem Based Learning

\begin{tabular}{|l|l|}
\hline Tahapan & \multicolumn{1}{|c|}{ Tindakan } \\
\hline Tahap 1 & $\begin{array}{l}\text { Orientasi peserta didik } \\
\text { pada masalah }\end{array}$ \\
\hline Tahap 2 & $\begin{array}{l}\text { Mengorganisasi peserta } \\
\text { didik untuk belajar }\end{array}$ \\
\hline Tahap 3 & $\begin{array}{l}\text { Membimbing } \\
\text { penyelidikan individual } \\
\text { maupun kelompok }\end{array}$ \\
\hline Tahap 4 & $\begin{array}{l}\text { Mengembangkan dan } \\
\text { menyajikan hasil karya }\end{array}$ \\
\hline Tahap 5 & $\begin{array}{l}\text { Menganalisis dan } \\
\text { mengevaluasi proses } \\
\text { pemecahan masalah }\end{array}$ \\
\hline
\end{tabular}

(Khayati, 2015:43)

Berdasarkan Tabel 1 tersebut, pembelajaran dimulai dengan menjelaskan tujuan pembelajaran dan aktivitas apa saja yang harus dilakukan guru dan peserta didik. Demikian juga dijelaskan bagaimana guru akan melakukan evaluasi. Dengan demikian, peserta didik dan guru akan saling terkoneksi sehingga tujuan pembelajaran dapat tercapai dengan baik. Peserta didik secara individu atau kelompok diberikan permasalahan yang berkaitan dengan materi yang akan diajarkan. Mereka diberi waktu untuk memahami per- 
masalahan tersebut. Proses pengaitan pemahaman awal peserta didik terjadi di tahapan ini. Pengontruksi pengetahuan peserta didik dibimbing oleh guru agar tetap terfokus pada tujuan yang telah disusun guru.

Peserta didik berdiskusi dengan tiap kelompoknya masing-masing yang sebelumnya telah dibentuk. Jika pembelajaran berlangsung secara individu, perlu kerja ekstra dari guru untuk membimbing setiap peserta didiknya. Pembentukan kelompok berdasarkan perbedaan tingkat kemampuan atau prestasi sehingga diharapkan terjadi diskusi yang efektif dan saling berbagi serta bekerja sama dan membagi tugas untuk menyelesaikan masalah.

Hasil analisis dan penyelesaian masalah dituliskan ke artefak atau bisa dalam catatan diskusi. Semua kegiatan yang telah terjadi dituliskan dengan baik. Hal ini bisa menjadi catatan bagi guru untuk melakukan perbaikan. Kekurangan dan keunggulan selama proses pembelajaran akan terlihat di sini. Guru dapat meminta peserta didik untuk mempresentasikan hasil diskusinya di depan kelas. Pembelajaran diakhiri dengan merefleksi dan mengklarifikasi hasil analisis atau penyelesaian masalah oleh guru. Penjelasan materi yang merupakan bagian penting ditekankan pada tahapan ini, dengan tujuan agar peserta didik tidak mengalami kesalahan dalam pengambilan kesimpulan.
Sistem penilaian dilakukan dengan memadukan tiga aspek yaitu pengetahuan (knowledge), kecakapan (skill), dan sikap (attitude). Pertama, penilaian pengetahuan diperoleh dari hasil laporan. Guru menganalisis dan memprediksi pengetahuan yang dimiliki peserta didik. Hasil laporan secara berdiskusi lebih sulit dalam melakukan penilaian daripada hasil laporan individu.

Kedua, penilaian kecakapan diukur dari penguasaan dan kemampuan peserta didik dalam menginterpretasikan jawaban pada suatu masalah. Jawaban peserta didik bertele-tele atau to the point menjadi bahan pertimbangan guru dalam melakukan penilaian.

Ketiga, penilaian sikap diperoleh dari keaktifan dan partisipasi dalam bekerja sama, membagi tugas dalam menyelesaikan masalah. Penilaian untuk peserta didik dalam modul yang dikembangkan peneliti berupa penilaian yang dilampirkan dalam modul setelah peserta didik melewati tahap latihan soal. Dalam modul telah dilampirkan kriteria pencapaian atau ketuntasan peserta didik, jika peserta didik telah mencapai batas ketuntasan minimal maka peserta didik tersebut bisa melanjutkan untuk mempelajari materi selanjutnya, namun jika skor peserta didik dalam latihan soal belum mencapai batas ketuntasan minimal, peserta didik tersebut harus mengulang mempelajari materi tersebut. 
Dalam hal ini, peserta didik bisa menilai dirinya sendiri.

\section{Keunggulan dan Kelemahan Model Pembelajaran Berbasis Masalah}

Pemecahan masalah merupakan teknik yang cukup bagus untuk lebih memahami isi pelajaran. Mengapa? Karena dengan memecahkan masalah berarti peserta didik sudah melibatkan diri secara aktif. Seperti yang dijelaskan sebelumnya bahwa model Problem Based Learning melibatkan pengetahuan awal peserta didik. Mereka mengoneksikannya dengan masalah yang diberikan guru. Jika mereka tidak memiliki pengetahuan awal yang berkaitan, mereka dapat bertanya dan berdiskusi dengan peserta didik lain. Pengetahuan diharapkan lebih bermakna jika model Problem Based Learning dilaksanakan dengan benar.

Pemecahan masalah dapat menantang kemampuan peserta didik serta memberikan kepuasan untuk menentukan pengetahuan baru bagi peserta didik. Selain itu, dapat membantu peserta didik untuk bertanggung jawab dalam pembelajaran yang mereka lakukan.
Melalui Problem Based Learning bisa memperlihatkan kepada peserta didik bahwa setiap mata pelajaran pada dasarnya merupakan cara berpikir, dan sesuatu yang harus dimengerti oleh peserta didik, bukan hanya sekadar belajar dari guru atau dari buku-buku. Belajar dapat dilakukan secara mandiri oleh peserta didik, tentunya dengan bimbingan dari guru atau orang tua. Peserta didik juga akan menyadari bahwa belajar itu hakikatnya adalah proses pengontekstualisasi diri ke dalam dunia belajar.

\section{PENUTUP}

Berdasarkan uraian di atas, dapat disimpulkan bahwa pembelajaran Problem Based Learning yang berpusat pada peserta didik dalam mengembangkan kemampuan berpikir tingkat tinggi. Pembelajaran Problem Based Learning adalah pembelajaran berbasis masalah dengan bantuan bimbingan guru. Peserta didik harus mampu menggali masalah, mengaitkannya dengan kom petensi, mengintegrasikannya dengan konsep matematika, dan menemukan solusi berdasarkan kemampuannya. 


\section{DAFTAR PUSTAKA}

Fitri, Amalia. 2011. Pengembangan Perangkat Pembelajaran Statistika Dasar Bermuatan Pendidikan Karakter dengan Metode Problem Based Learning. Jurnal PP volum 1. No 2. ISSN 2089-3639. [Online]. Tersedia: http://www. journal.unnes.ac.id/nju/index.php/jpppasca/article/view/1540+\&cd=1\&hl=id\&ct=clnk\& $\mathrm{gl}=\mathrm{id}$

Gunantara, dkk. 2014. Penerapan Model Pembelajaran Problem Based Learning Untuk Meningkatkan Kemampuan Pemecahan Masalah Matematika Siswa Kelas V. Jurnal Mimbar PGSD Universitas Pendidikan Ganesha Jurusan PGSD (Vol: 2 No: 1 Tahun 2014). [Online]. Tersedia: http://ejournal.undiksha.ac.id/index.php /JJPGSD/article/view/2058

Hariyati, dkk. 2013. Efektivitas Model Pembelajaran Kooperatif Tipe Team Assisted Individualization (TAI) dan Problem Based Learning (PBL) Pada Prestasi Belajar Matematika Ditinjau Dari Multiple Intelligences Siswa SMP Kabupaten Lampung Timur Tahun Pelajaran 2012/2013. Jurnal Elektronik Pembelajaran Matematika Vol. 1 No. 7, hal. 721-731, Desember 2013. [Online]. Tersedia: http://www.jurnal.fkip.uns.ac.id/index.php/s2math/article/view/3544

Herman, Tatang. (2007). Pembelajaran Berbasis masalah untuk Meningkatkan Kemampuan Berpikir Matematis Tingkat Tinggi Siswa Sekolah Menengah Pertama. [Online]. Tersedia: Educationist. No 1 Vol. 1 Januari 2007. http://eprints.uny.ac.id/11994/1/PM\%20-\%2039\%20Tatang\%20Herman.html

Khayati, Fitrotul. 2015. Pengem- bangan Modul Matematika Untuk Pembelajaran Berbasis Masalah (Problem Based Learning) Pada Materi Pokok Persamaan Garis Lurus Kelas VIII SMP (Tesis). [Online]. Tersedia: http://digilib.uns.ac.id/dokumen/detail/43323/pengembangan-modul-matematika-untukpembelajaran-berbasis-masalah-problem-based-learning-pada-materi-pokok-persamaan -garis-lurus-kelas-viii-smp

Permana \& Sumarmo. 2007. Mengembangkan kemampuan penalaran dan koneksi matematik siswa SMA melalui pembelajaran berbasis masalah. [Online]. Tersedia: Educationist $\begin{array}{lllll}\text { Vol. } & 1 & \text { No. } & 2007 .\end{array}$ http://file.upi.edu/Direktori/JURNAL/EDUCATIONIST/Vol._I_No._2-

Juli_2007/6_Yanto_Permana_Layout2rev.html

Ratnaningsih, N. 2003. Pengembang- an Kemampuan Berfikir Matematik Peserta didik Smu Melalui Berbasis Masalah. (Tesis). Tersedia: http://ejournal.unp.ac.id/students/index.php/pmat/article/download/1152/844 